is, as usual, a large volume (Pp. xii $+595+100$ plates. Washington, D.C.: Government Printing Offico, 1964. 4.25 dollars). It includes original papers by members of the staff and others, in addition to tho usual statistics. Such papors includo one on the Solar systom by Sir Bernard Lovell, another on the use of the electron microscope in the examination of fossils, and also one on the futuro of underwater archaeology. The most notablo development during the year was tho progress made in the completion of the great new Musoum of History and Technology building. It will contain 50 exhibition halls, and spaco has been set aside for the extensive reserve collections of the Institution.

The Wellcome Historical Medical Museum and Library

Forlowrac the completion of the reorganization of the Wellcome Historical Medical Library, plans aro now being prepared for a great expansion of the Wellcome Historical Medical Museum. The Trustees havo ensured that the Musoum shall have all the accommodation required to fulfil the aims of its founder and (for the first time) make all its collections on the history of medicine and science generally available for study and research. New exhibitions and study gallerios now being planned include a synoptic exhibition on the history of modicino from earliest times to the present day, and an exhibition about medicine in art which will be concentrated on the art objects from the Museum's collections. In addition to these new permanent sections for the Musoum, adoquate space has been allocated for temporary special exhibitions in which individual topics of particular medical or sciontific importance will be dealt with.

\section{Publications of the World Health Organization}

THE World Health Organization publishes a number of periodicals, and in addition a number of roports at irrogular intervals. The former include the Bulletin of the World Health Organization, WHO Chronicle and the International Digest of Health Legislation. Tho lattor includo the WHO Technical Report Series and the WHO Monograph Series. A bibliography of all these publications has been published for the years 1947-57, and recontly that covering tho years 1958-62 appoarod (Pp. 125. Geneva: World Hoalth Organization; London: H.M.S.O., 1965. 12 Sw. francs; $208 . ; 4$ dollars). It classifies the articles undor soparate headings, first the technical articles and thon administration and general articles. There is also an author index and an index of countries. We can thus now have fairly up-to-date information of what it is that the World Health Organization has been publishing; one somotimos feels that it would bo an even greater boon if one could have easier access to some of the publications themselves.

\section{Benzene Centenary}

$\Lambda_{\mathrm{N}}$ outstanding contribution to organic chemistry carne 100 years ago with F. Kekulés conception of the ring structuro of benzeno. In the Bulletin de la Societé Chimique in 1865, Kekulé, a pupil of Liebig while at Giessen, published his thesis "On the Constitution of Aromatic Compounds", in which he put forward the idea of a hoxagonal structure of carbon atoms-thus explaining the fact that no aromatic compound contains loss than six carbon atoms. Ho reforred to six "unsatisfied affinities" in the structure, and suggested the well-known 'Kekule ring' with alternate single and double bonds in tho linking. Kekule made many predictions on tho basis of his theory, rather like Mondoloov, who kopt on forecasting new elements from his Periodic Law. Thus, after referring to the benzene 'nucleus' and to 'sido-chains', Kekulé showed how homologues of benzone were possible when the number of side-chains or their lengths were increased. Accordingly, he maintained that there should be three dimethylbonzenes and one othylbenzene. In deducing the number of possiblo substitution products in the case of the dibromonitrobenzenes, for example, he enabled Körner to formulate his orientation scheme. Lator, Erlenmoyer extended Kekuló's structuro to the constitution of naphthalene, while Dewar extended the 'aromatic" theme to include pyridine and quinoline structures. 'Tho bonzono theory substantiates Kekulé's claim to a nicho in chomical history: seven years pre. viously he had laid a foundation to this claim with his "Theory of Molecular Structure" in the Annalen der Chemie of 1858 , with his conception of linking between quadrivalent carbon atoms to form chains.

\section{Soil and Pasture Research in Australia}

THE Northern Tablelands of Now South Walos form one of the natural regions of the Great Dividing Range, comprising some eight million acros in the north-east of New South Wales, lying in the summor-rainfall zone and of average olevation 2,500 ft. A freely illustrated publication prepared by the Commonwoalth Scientific and Industrial Rosoarch Organization, in co-oporation with tho New South Wales Department of Agriculture, givos an account of the establishmont and maintenance of pastures on the Tablelands for the fooding of four million sheop and 300,000 cattle (Soil and Pasture Research on the Northern Tablelands, New South Wales. Pp. 81. Molbourne: Commonwealth Scientific and Industrial Resoarch Organization, 1964). There is a frost-free period of about six months, but the native grasses are checked and are unpalatable during the winter. Tho total rainfall is a little more than 30 in., but 60 per cent falls in the summor, and does not maintain an adequato supply of water for plant growth. The deficiency, however, is usually not large and may be overcomo by fallowing, constructing contour banks or by irrigation. The important broad groups of soils aro solodic with alkaline clay sub-soil and podsolic with neutral or acid sub-soil, both on sedimontary or granite, and black earths which are dark-coloured clays dorived from basalt. More than 80 per cont of the species of native pastures consist of perennial grasses and are unablo to provide wintor feed; sown pastures of grasses and clovers, on tho othor hand, have a high production potential. Experimental evidence indicates that the major nutrients lacking are nitrogen, phosphorus and sulphur; of the trace olements, boron and molybdenum are deficient in some soils. The introduction of clovers is highly desirable, but there are problems concorning locality and nodulation that still havo to be solved. In the meantime, it seems that 'strategic grazing' would be the most effective policy.

\section{Problems of Cooley's Anaemia}

'THe wide interest displayed in tho probloms of 'Cooley's anaomia' is reflected by the rocont publication of the transactions of a three-day conference held in New York (Annals of the New York Academy of Sciences, 119, Articlo 2: Problems of Cooley's Anemia, by Harold Fink and 76 other authors. Pp. 369-850. New York: New York Acidemy of Seioncos, 1964. 8 dollars). Thoro aro papors by gonoticists, biochemists and clinical sciontists and the volume gives a comprehensive view of the latest advances in this area of research. The numbor of thoorios advancod to explain tho various findings in this disease shows that we are still some way from an explanation of what has gone wrong, but a great deal of information on different aspects of this disease is collected in this symposium which should be of considerable value to workers in this field.

\section{University News:}

Oxford

The Committee appointed by the Hebdomadal Council to make detailed proposals for tho closer integration of university teaching and research with the college system at the University of Oxford has now roported (P.p. 10. Supplement No. 1 to the University Gazette, Novomber 1964. Oxford: The University, 1964. 6d.). Concluding that there must be a clear definition of university posts 